\title{
Implementasi Peraturan Pengawasan Kosmetik Tanpa Izin Edar dalam Perdagangan Melalui Sistem Elektronik sebagai Upaya Perlindungan Konsumen
}

\author{
Putri Nur Anisa*, Tatty Aryani Ramli \\ Prodi Ilmu Hukum, Fakultas Hukum, Universitas Islam Bandung, \\ Indonesia. \\ *putrinuranisa.pna@gmail.com, tattyramli@gmail.com
}

\begin{abstract}
Cosmetics based on positive law are pharmaceutical preparations that can only be circulated after obtaining a marketing permit. A marketing permit is a form of consumer protection to ensure the safety of a cosmetic product. Responding to the circulation of cosmetics that do not have a marketing permit in electronic commerce, the government established regulations on the supervision of cosmetic circulation with the ultimate goal of providing guarantees of consumer protection certainty. This research aims to find out the implementation of surveillance that has been done and to find out the factors that cause the ineffectiveness of supervision in protecting consumers. This research method uses a normative juridical approach with analytical descriptive research specifications. The results showed that the implementation of supervision was following cosmetic supervision regulations and had included stages of consumer protection. Factors that cause ineffective supervision occur due to applicable regulations, law enforcement, and the level of knowledge and public awareness is still weak. So that the results of supervision can guarantee the plan in the purpose of the regulation can not be realized.
\end{abstract}

Keywords: Marketing Permit, Cosmetics, E-Commerce, Consumers Protection.

\begin{abstract}
Abstrak. Kosmetik berdasarkan hukum positif merupakan sediaan farmasi yang hanya dapat beredar setelah mendapatkan izin edar. Izin edar merupakan bentuk perlindungan konsumen untuk menjamin keamanan suatu produk kosmetik. Menyikapi peredaran kosmetik yang tidak memiliki izin edar dalam perdagangan elektronik, pemerintah membentuk peraturan tentang pengawasan peredaran kosmetik dengan tujuan akhir memberikan jaminan kepastian perlindungan konsumen. Penelitian ini bertujuan untuk mengetahui implementasi pengawasan yang telah dilakukan dan untuk mengetahui faktor-faktor yang menjadi penyebab tidak efektifnya pengawasan dalam melindungi konsumen. Metode penelitian ini menggunakan pendekatan yuridis normatif dengan spesifikasi penelitian deskriptif analitis. Hasil penelitian menunjukan bahwa implementasi pengawasan yang dilakukan telah sesuai dengan peraturan pengawasan kosmetik dan telah mencakup tahap-tahap perlindungan konsumen. Faktor penyebab tidak efektifnya pengawasan terjadi karena peraturan yang berlaku, aparat penegak hukum, serta tingkat pengetahuan dan kesadaran masyarakat yang masih lemah. Sehingga yang seharusnya hasil pengawasan dapat menjamin rencana dalam tujuan peraturan tidak dapat terwujud.
\end{abstract}

Kata Kunci: Izin Edar, Kosmetik, Perdagangan Melalui Sistem Elektronik, Perlindungan Konsumen. 


\section{A. Pendahuluan}

Perkembangan pengguna internet di Indonesia pada tahun 2017 mengalami kenaikan mencapai 143,26 juta jiwa.[1] Tingginya pengguna internet berdampak terhadap perkembangan model transaksi perdagangan dari konvensional menjadi serba elektronik atau dikenal dengan istilah e-commerce. Model bisnis e-commerce dalam peraturan di Indonesia disebut Perdagangan Melalui Sistem Elektronik (selanjutnya disebut PMSE). Pada saat ini PMSE menjadi bisnis yang banyak digunakan oleh masyarakat karena memiliki kelebihan jangkauan pasar luas dan dapat menekan biaya yang harus dikeluarkan.[2]

PMSE selain memberikan manfaat juga menjadi tantangan besar yang harus dihadapi oleh para konsumen. Pada era PMSE ini, pelaku usaha seringkali menempatkan konsumen pada posisi daya tawar lemah. Hal tersebut sebab melalui PMSE konsumen cenderung akan kesulitan untuk mendapatkan informasi yang benar dan jujur dari pelaku usaha, serta sulitnya mengidentifikasi suatu produk. Dampak negatif tersebut tidak terlepas dari faktor kurangnya pengawasan, serta peraturan perundang-undangan yang belum mendukung.[3]

Permasalahan PMSE pada saat ini juga terjadi dalam bisnis kosmetik. Kosmetik adalah sediaan farmasi atau bahan yang digunakan untuk merubah penampilan, merawat, dan memperbaiki kondisi kulit. Sebagai produk kebutuhan sehari-hari dan didukung dengan perkembangan PMSE, hal tersebut memunculkan itikad buruk dari pelaku usaha dengan mengedarkan kosmetik yang tidak memiliki izin edar dan mengandung bahan berbahaya. Padahal berdasarkan Pasal 106 Undang-Undang Nomor 32 Tahun 2009 tentang Kesehatan telah diatur bahwa kosmetik hanya dapat diedarkan setelah mendapatkan izin edar, dengan tujuan untuk menjamin keamanan produk bagi konsumen.

Peredaran kosmetik yang tidak memiliki izin edar dalam PMSE pada saat ini menjadi trending topic dalam masyarakat. Peredaran kosmetik yang tidak memiliki izin edar dalam PMSE seringkali menyeret sejumlah nama public figure di Indonesia. Permasalahan peredaran kosmetik dalam PMSE juga membuat beberapa dokter ikut turun dan mengedukasi masyarakat berkaitan dengan dampak-dampak dari penggunaan kosmetik yang tidak memiliki izin edar. Namun karena tingginya permintaan konsumen terhadap kosmetik dan tingkat pengetahuan konsumen yang masih lemah, pada tahun 2019 ditemukan adanya peningkatan jumlah peredaran kosmetik tanpa izin edar dalam PMSE mencapai lebih dari 50\% dibandingkan dengan tahun 2017 dan 2018.[4] Kasus peredaran kosmetik dalam PMSE yang ditemukan ternyata sebagian besar terjadi pada PMSE model consumers to consumers, dimana biasanya model consumers to consumers tersebut akan menyulitkan konsumen memintai pertanggung jawaban di kemudian hari dan sulit bagi konsumen mengenali identitas pelaku usaha.

Seiring dengan perkembangan permasalahan kosmetik pada saat ini, pemerintah telah membentuk beberapa peraturan tentang pengawasan kosmetik dalam PMSE. Peraturan pengawasan yang dibentuk oleh pemerintah terdiri dari peraturan pengawasan secara preventif maupun pengawasan secara represif. Selain penetapan peraturan, pemerintah melalui Badan Pengawas Obat dan Makanan (BPOM) juga telah melakukan berbagai upaya pengawasan terhadap peredaran kosmetik dalam PMSE, sebagai upaya jaminan keamanan dan keselamatan konsumen. Pembentukan peraturan pengawasan mengacu kepada semangat Undang-Undang Nomor 8 Tahun 1999 tentang Perlindungan Konsumen. Peraturan pengawasan yang berlaku berpedoman pada tujuan untuk melindungi konsumen dari dampak negatif penggunaan suatu produk dengan sistem perlindungan yang memberikan kepastian dan keterbukaan informasi, meningkatkan kesadaran pelaku usaha, serta meningkatkan kemandirian konsumen dalam melindungi diri.

Permasalahannya adalah meskipun peraturan mengenai pengawasan kosmetik dalam PMSE telah diimplementasikan oleh BPOM, kasus peredaran kosmetik yang tidak memiliki izin edar dalam PMSE consumers to consumers masih banyak terjadi bahkan tidak sedikit menimbulkan kerugian bagi konsumen. Permasalahan tersebut juga diakui BPOM dengan menegaskan bahwa sistem perdagangan elektronik yang berlaku terutama dengan model consumers to consumers sulit diimbangi dan sulit untuk diawasi.[5] Sehingga peredaran kosmetik tanpa izin edar masih terus berlangsung meskipun BPOM telah melakukan berbagai upaya untuk melindungi konsumen melalui pemblokiran konten-konten hingga akun yang 
mengedarkan kosmetik tanpa izin edar. Adanya permasalahan tersebut jelas tidak sesuai dengan Pasal 4a Undang-Undang Nomor 8 Tahun 1999 tentang Perlindungan Konsumen yang mengatur mengenai jaminan keamanan dan keselamatan konsumen. Maka dengan demikian perlu diteliti lebih lanjut bagaimana implementasi pengawasan kosmetik dalam PMSE sebagai bentuk perlindungan konsumen.

Tujuan dari penelitian ini adalah untuk mengetahui kesesuaian implementasi pengawasan kosmetik dalam PMSE dengan peraturan yang berlaku. Kedua untuk mengetahui faktor-faktor penghambat pengawasan dalam mewujudkan perlindungan konsumen kosmetik dalam PMSE.

\section{B. Metodologi Penelitian}

Penelitian ini menggunakan metode penelitian yuridis normatif dengan spesifikasi penelitian deskriptif analitis menggunakan data sekunder berupa peraturan-peraturan yang berkaitan dengan pengawasan kosmetik dalam PMSE. Metode analisis yang digunakan adalah analisis kualitatif dengan penarikan fakta yang bersifat umum untuk menjawab permasalahan secara khusus.

\section{Hasil Penelitian dan Pembahasan}

\section{Implementasi Peraturan Pengawasan Kosmetik dalam PMSE}

Peraturan pengawasan kosmetik di PMSE diatur dalam Peraturan Pemerintah Nomor 80 Tahun 2019 tentang Perdagangan Melalui Sistem Elektronik (selanjutnya disebut PP PMSE). Selain itu berkaitan dengan kosmetik telah dibentuk juga beberapa peraturan BPOM seperti, Peraturan BPOM Nomor 33 Tahun 2018 tentang Penerapan 2D Barcode dalam Pengawasan Obat dan Makanan (selanjutnya disebut Perka BPOM No.33/2018). Peraturan BPOM Nomor 8 Tahun 2020 tentang Pengawasan Obat dan Makanan yang Diedarkan Secara Daring (selanjutnya disebut Perka BPOM No.8/2020). Serta Peraturan BPOM Nomor 12 Tahun 2020 tentang Tata Cara Pengajuan Notifikasi Kosmetika. Keempat peraturan tersebut memiliki tujuan yang sama yaitu untuk menjamin dilaksanakannya kewajiban izin edar kosmetik melalui pengawasan yang sifatnya preventif maupun represif.

Pelaksanaan pengawasan kosmetik dalam PMSE berdasarkan hasil penelitian menunjukan bahwa implementasinya telah sesuai dengan ketentuan peraturan pengawasan yang berlaku. Pengawasan yang dilakukan pemerintah terutama dalam hal ini adalah BPOM telah sampai pada tahap pengawasan preventif dan represif. Tahapan preventif yang dilakukan oleh BPOM adalah tahapan perlindungan konsumen sebelum kosmetik beredar dengan cara memberikan akses kemudahan permohonan izin edar yang dapat dilakukan secara online melalui Notifkos BPOM. Pemerintah juga dalam tahap pengawasan ini telah melakukan pengujian-pengujian terhadap kosmetik-kosmetik sebelum dikeluarkannya izin edar dengan tujuan untuk menjamin keamanan produk. Tahap berikutnya adalah tahapan pengawasan represif, tahap pengawasan represif adalah upaya-upaya perlindungan konsumen yang dilakukan setelah kosmetik beredar dalam PMSE. Untuk menjamin kosmetik yang beredar dalam PMSE tidak berbahaya bagi konsumen, BPOM telah melakukan upaya kerjasama untuk pemantauan terhadap konten-konten kosmetik yang tidak memiliki izin edar dan kerjasama untuk melakukan penurunan konten maupun pemblokiran akun pelaku usaha yang menawarkan kosmetik tanpa izin edar. Tidak hanya sampai disitu, BPOM juga terus berusaha melakukan pengawasan secara langsung ke tempat-tempat yang diduga sebagai tempat untuk mengedarkan kosmetik yang tidak memiliki izin edar ke PMSE. Hasil dari pengawasan baik secara langsung maupun dalam sistem elektronik, BPOM kemudian menyebarluaskan informasi tersebut melalui berbagai media dengan tujuan hasil pengawasan dapat diketahui oleh konsumen, dan konsumen dapat terhindar dari kosmetik-kosmetik yang tidak memiliki izin edar dan membahayakan kesehatan. Pada pelaksanaan pengawasan secara represif, BPOM juga memberikan kemudahan akses bagi konsumen untuk mengetahui berbagai informasi kosmetik dan melakukan pengecekan terhadap keamanan produk dengan pembentukan aplikasi BPOM Mobile. Aplikasi tersebut dapat digunakan untuk melakukan scan 2D Barcode kosmetik yang tertera pada kemasan, melakukan pengecekan mengenai izin edar, sampai dengan sarana pengaduan 
konsumen.

Upaya-upaya pengawasan yang dilakukan oleh BPOM telah sesuai dengan peraturan pengawasan kosmetik dalam PMSE yang berlaku pada saat ini. Upaya yang dilakukan juga telah mencakup perlindungan konsumen dari sebelum beredar sampai dengan setelah beredarnya produk kosmetik sebagaimana yang dijelaskan oleh Johanes Gunawan.[6] Namun pelaksanaan pengawasan tersebut ternyata belum dapat menjamin keamanan dan keselamatan konsumen ketika menggunakan produk kosmetik. Padahal berdasarkan ketentuan Pasal 4 Undang-Undang Nomor 8 Tahun 1999 tentang Perlindungan Konsumen, diatur bahwa konsumen berhak atas keamanan dan keselamatan, dimana seharusnya tidak boleh ada konsumen yang menderita kerugian fisik maupun psikis atas penggunaan suatu produk. Dengan adanya pengawasan oleh BPOM juga seharusnya pemerintah dapat melindungi dan menjamin terlaksananya peraturan perlindungan konsumen oleh para pelaku usaha, tetapi kenyataannya hal tersebut belum tercapai. Maka dengan demikian, berarti pelaksanaan peraturan pengawasan yang dilakukan oleh BPOM belum sampai kepada tahap menjamin suatu hasil sesuai dengan rencana.[7] Dalam arti lain hasil pengawasan yang dilakukan oleh BPOM belum sesuai dengan rencana yang tertuang tujuan peraturan pengawasan kosmetik dalam PMSE untuk memberikan jaminan perlindungan bagi konsumen.

\section{Faktor-faktor penghambat pengawasan dalam melindungi Konsumen}

Pelaksanaan implementasi pengawasan oleh BPOM yang belum dapat mencapai tujuan perlindungan konsumen terjadi karena beberapa faktor. Faktor-faktor yang mempengaruhi tidak efektifnya implementasi pengawasan oleh BPOM terjadi karena faktor substansi hukum, penegak hukum, dan tingkat pengetahuan masyarakat yang masih rendah. Faktor-faktor tersebut diuraikan sebagai berikut :

1. Peraturan pengawasan kosmetik dalam PMSE yang berlaku pada saat ini masih terdapat kelemahan yang memberikan celah untuk pelaku usaha menawarkan kosmetik yang tidak memiliki izin edar. Kelemahan peraturan pengawasan tersebut terdapat dalam PP PMSE dan Perka BPOM No.8/2020.

- PP PMSE memiliki kelemahan dalam mengatur pengawasan kosmetik. Hal ini karena dalam ketentuan Pasal 23b yang mengatur mengenai kewajiban penyediaan sarana kontrol teknologi dan sarana aduan atau laporan masyarakat masih menjadi pilihan bagi platform penyelenggara perdagangan melalui sistem elektronik. Platform masih boleh memilih untuk menyediakan kedua sarana tersebut, atau hanya memilih salah satunya. Kelemahan berikutnya dalam ketentuan Pasal 23b PP PMSE adalah peraturan tidak mengatur apa itu sarana kontrol teknologi harus seperti bagaimana sarana kontrol teknologi tersebut sehingga dapat menjamin tidak adanya konten kosmetik yang tidak memiliki izin edar dalam PMSE. Dengan tidak diaturnya secara detail maka hal ini akan menimbulkan berbagai penafsiran dari berbagai platform mengenai sarana kontrol itu sendiri, sehingga tidak terwujudnya keseragaman dalam rangka melindungi konsumen. Padahal seharusnya ketentuan Pasal 23b PP PMSE mengatur secara tegas bahwa sarana kontrol adalah wajib disediakan oleh platform dan mengatur lebih rinci harus seperti bagaimana sarana tersebut. Sehingga Pasal 23b ini akan menjadi ketentuan yang sangat berperan penting dalam pengawasan peredaran kosmetik yang tidak memiliki izin edar, karena melalui sarana kontrol teknologi tersebut diharapkan konten-konten penawaran kosmetik yang tidak memiliki izin edar dapat disaring secara otomatis oleh sistem sebelum produk masuk dan beredar dalam sistem PMSE.

- Kemudian berkaitan dengan kelemahan Perka BPOM No.8/2020, terdapat dalam ketentuan Pasal 32 berkaitan dengan sanksi. Dalam Pasal 32 ayat (1) mengatur bahwa sanksi administrasi atas pelanggaran terhadap ketentuan kewajiban izin edar kosmetik dalam PMSE yang diberikan baik untuk pelaku usaha dan penyelenggara sistem elektronik atau disebut juga dengan platform. Tetapi dalam ketentuan Pasal 32 ayat (2) sanksi-sanksi yang diberikan lebih fokus terhadap merchant-merchant. Meskipun benar sanksi administrasi peringatan dan peringatan keras juga berlaku 
untuk platform yang melanggar, akan tetapi sanksi tersebut tidak seimbang dengan sanksi yang diterima oleh merchant. Padahal dalam kenyataannya tidak jarang ditemukan platform yang juga merupakan mitra BPOM dalam melakukan pengawasan, ikut melanggar ketentuan-ketentuan mengenai kewajiban izin edar kosmetik dengan mengiklankan produk kosmetik yang tidak memiliki izin edar melalui berbagai media sosialnya. Seharusnya peraturan pengawasan memberikan kesimbangan kedudukan dan keadilan antara pelaku usaha platform dengan konsumen[8] dengan menambahkan sanksi bagi platform, baik berupa sanksi denda atau lainnya sehingga platform akan lebih berhati-hati dalam memberikan layanan iklan melalui berbagai media sosialnya. Mengingat dalam PMSE ini pelaku usaha tidak hanya merchant dalam sistem elektronik, tetapi juga termasuk mereka para platform.

2. Faktor berikutnya adalah penegak hukum yang tidak bisa menjangkau model bisnis kosmetik PMSE consumers to consumers. Perdagangan kosmetik yang tidak memiliki izin edar ternyata banyak ditemukan dalam PMSE model consumers to consumers. BPOM menegaskan bahwa dengan model consumers to consumers sulit untuk dilakukan pengawasan. Upaya-upaya perlindungan penurunan konten dan pemblokiran akun juga ternyata masih belum efektif karena model consumers to consumers masih memberikan kemudahan bagi pelaku usaha untuk mengedarkan kosmetik tanpa izin edar melalui pembuatan akun baru. Selain model PMSE yang sulit untuk diawasi oleh BPOM, pada tahap perlindungan konsumen melalui pengenaan sanksi yang diberikan terhadap platform belum maksimal karena tidak memberikan efek jera. Hal ini terjadi karena memang peraturan mengenai sanksi yang ada tidak mengatur hal tersebut.

3. Terakhir adalah tingkat pengetahuan masyarakat yang masih rendah baik itu konsumen, pelaku usaha, dan penyelenggara sistem elektronik.

- Berdasarkan penelitian, ditemukan masih ada pelaku usaha yang tidak mengetahui bahwa izin edar kosmetik adalah wajib sebelum produk diedarkan baik secara konvensional maupun dalam PMSE. Pelaku usaha khususnya reseller juga seringkali mengabaikan untuk melakukan pengecekan kembali bahwa produk yang dijual benar telah aman dan memiliki izin edar.

- Platform sebagai pelaku usaha, dalam perlindungan konsumen kosmetik tingkat kesadaran hukumnya lemah. Beberapa kali platform yang bekerjasama dengan BPOM kedapatan melanggar ketentuan kewajiban izin edar melalui iklan kosmetiknya. Padahal BPOM menegaskan bahwa kerjasama antara BPOM dengan Indonesian E-commerce Association (IdeA) salah satu bentuknya adalah pertukaran informasi berkaitan dengan pengawasan kosmetik. Maka seharusnya platform sudah mengetahui dan sadar produk apa yang boleh dipromosikan melalui iklan dan produk kosmetik mana yang tidak boleh dipromosikan.

- Pengetahuan konsumen tentang izin edar masih lemah. Selain pelaku usaha, konsumen juga menjadi faktor yang paling berpengaruh terhadap peredaran kosmetik yang tidak memiliki izin edar dalam PMSE. Pada saat ini masih ada konsumen yang salah mendefinisikan izin edar yang menganggap itu sama dengan label berisi kelengkapan informasi suatu produk. Padahal izin edar produk adalah berupa nomor izin yang biasanya terdiri dari 11 angka dan dikeluarkan oleh BPOM setelah produk kosmetik dinyatakan aman berdasarkan hasil pengujian. Selain kesalahan mendefinisikan izin edar, ternyata sarana-sarana yang telah disediakan oleh BPOM untuk memberikan kemudahan akses informasi keamanan produk kosmetik belum sepenuhnya diketahui oleh masyarakat. Sehingga tidak heran tujuan untuk meningkatkan kemandirian konsumen dalam melindungi diri melalui peraturan dan implementasinya belum tercapai.

Dari uraian tersebut jelas bahwa yang menghambat terciptanya perlindungan konsumen melalui pengawasan tidak hanya karena faktor hukum. Untuk dapat mewujudkan perlindungan hukum yang maksimal juga harus didukung oleh kesadaran hukum masyarakat. Berdasarkan uraian diatas dapat disimpulkan bahwa implementasi peraturan pengawasan kosmetik dalam 
PMSE yang telah dilaksanakan oleh BPOM masih belum mencapai tahap mewujudkan hasil yang sesuai dengan rencana dalam peraturan. Tidak terwujudnya hasil pengawasan yang sesuai dengan rencana terjadi karena beberapa faktor. Sehingga berbagai pelaksanaan pengawasan oleh BPOM yang seharusnya dapat meningkatkan kesadaran pelaku usaha dan meningkatkan kemandirian konsumen dalam melindungi dirinya melalui keterbukaan informasi belum dapat terwujud. Pelaksanaan pengawasan juga belum dapat memberikan kepastian jaminan keamanan dan keselamatan bagi konsumen kosmetik dalam PMSE.

\section{Kesimpulan}

Berdasarkan pembahasan dalam penelitian ini, peneliti menyimpulkan beberapa hasil penelitian sebagai berikut:

1. Pelaksanaan pengawasan kosmetik dalam PMSE oleh BPOM telah sesuai dengan peraturan pengawasan yang berlaku dan tahapan perlindungan konsumen. Namun pelaksanaan pengawasan belum sampai pada tahap menjamin hasil pengawasan sesuai dengan rencana dan tujuan yang diatur dalam peraturan pengawasan kosmetik yang berlaku.

2. Faktor-faktor yang mempengaruhi pengawasan belum efektif dalam memberikan perlindungan konsumen terjadi karena peraturan hukum yang berlaku masih lemah, penegakan hukum yang tidak ditunjang dengan sarana yang memadai, dan tingkat pengetahuan konsumen maupun kesadaran hukum pelaku usaha yang masih rendah.

\section{Acknowledge}

Tanpa mengurangi rasa syukur kepada Allah SWT, pertama penulis sampaikan terimakasih yang sedalam-dalamnya kepada kedua orangtua yang telah tulus mendukung penulis hingga penulis ada dalam fase ini. Penulis juga sampaikan terimakasih kepada:

1. Bapak Dr.Efik Yusdiansyah S.H., M.Hum yang telah memberikan saran dan masukan terhadap penelitian ini.

2. Ibu Hj. Tatty Aryani Ramli S.H., M.H. yang dengan tulus dan sabar membantu serta membimbing penulis dalam menyelesaikan penelitian ini.

3. Ibu Hj. Liya Sukma Muliya, S.H.,M.H. selaku Dosen Wali.

4. Para Dosen Fakultas Hukum Universitas Islam Bandung.

5. Teman dan sahabat yang telah membantu yang tidak dapat disebutkan satu persatu.

6. Pengurus Himpunan Mahasiswa Perdata dan Bisnis Periode 2021-2022.

7. Dan semua pihak yang membantu dalam pengerjaan penelitian ini yang tidak dapat disebutkan satu-persatu.

Dengan rasa syukur, semoga Allah senantiasa membalas kebaikan-kebaikan yang telah diberikan kepada penulis.

\section{Daftar Pustaka}

[1] Sulasi Rongiyati dari Asosiasi Penyelenggara Jaringan Internet Indonesia, Hasil Survei Penetrasi dan Perilaku Pengguna Internet Indonesia 2017, https://www.apjii.or.id , (diakses 13 Januari 2022 Pukul 09.47 WIB).

[2] Deky Pariadi, "Pengawasan E-Commerce dalam Undang-Undang Perdagangan dan UndangUndang Perlindungan Konsumen", Jurnal Hukum \& Pembangunan, Vol.48, No. 3, 2018.

[3] Celina Tri Siwi K, Hukum Perlindungan Konsumen, Sinar Grafika, Jakarta, 2011.

[4] Dina Manafe, BPOM: Nilai Temuan Kosmetik Ilegal Meningkat Drastis, https://www.beritasatu.com/kesehatan/606211/bpom-nilai-temuan-kosmetik-ilegalmeningkat-drastis, (diakses 26 Desember 2021 Pukul 19.03 WIB).

[5] Wawancara dengan Reghi Perdana dan Henny Mildawaty di Bandung, 25 Oktober 2021.

[6] Johanes Gunawan, Hukum Perlindungan Konsumen, Universitas Katolik Parahyangan, Bandung, 1999.

[7] Fajlurrahman Jurdi, Hukum Tata Negara Indonesia, Cet. Pertama, Kencana, Jakarta, 2019.

[8] Undang-Undang Nomor 8 Tahun 1999 tentang Perlindungan Konsumen. 